\title{
SEDIMEN LAUT SEBAGAI PROXY DALAM MENENTUKAN DINAMIKA IKLIM DI MASA LAMPAU
}

\author{
Oleh \\ Septriono Hari Nugroho ${ }^{1}$ )
}

\begin{abstract}
MARINE SEDIMENT AS PROXY TO DETERMINE CLIMATE DYNAMICS

IN THE PAST. Studying the dynamics of climate change in the past is important and necessary, because it can serve as a basis for understanding the modern climate and the causes of its variations and changes. Evidence of past climatic conditions is usually archived on traces in nature that provide a proxy of past climatic conditions that we can explore. One of the major sources of proxy data for paleoclimate reconstruction is marine sediment. Microfossils usually used for quantitative proxy is foraminifer, diatom, pollen and etc. For the purposes of paleoclimate, the most important material is foraminifera. The paleoclimate results from the remains of carbonate and silica organisms have been generated from four types of analyzes: (a) oxygen isotope composition, especially calcium carbonate in foraminifer test (b) quantitative interpretation of species and its spatial variation through (c) the ratio of $\mathrm{Mg} / \mathrm{Ca}$ to the foram test, which is related to temperature, and (d) the morphological variation in certain species resulting from environmental factors.
\end{abstract}

\section{PENDAHULUAN}

Paleoklimatologi merupakan studi tentang iklim sebelum periode pengukuran instrumental. Periode pengukuran instrumental adalah periode sejarah bumi yang tercatat dengan jelas dan pasti. Catatan instrumental hanya mencakup sebagian kecil $\left(<10^{-7}\right)$ dari sejarah iklim bumi dan memberikan perspektif yang sama sekali tidak memadai mengenai variasi iklim dan evolusi iklim saat ini. Perspektif yang lebih panjang tentang variabilitas iklim dapat diperoleh dengan mempelajari fenomena alam yang bergantung pada iklim. Alam banyak memberikan tanda mengenai perubahan iklim yang pernah terjadi di masa lalu. Ketika penyebab fluktuasi iklim masa lalu dipahami, perkiraan variasi iklim di masa depan akan jauh lebih akurat (Bradley, 2015).

Penelitian iklim masa lalu harus dimulai dengan pemahaman tentang jenis data proxy yang tersedia dan metode yang digunakan dalam analisisnya. Harus disadari pula kesulitan yang terkait dengan setiap metode yang digunakan. Menurut Bradley (2015), Zaman Kuarter yang mencakup kurang lebih 2 juta tahun yang lalu adalah periode perubahan besar lingkungan, mungkin yang terbesar selama 60 juta tahun

\footnotetext{
$\overline{{ }^{1)} \text { Pusat Penelitian Laut Dalam, LIPI }}$
} 
terakhir. Catatan isotop oksigen dari sedimen laut dalam yang kaya karbonat memberikan perspektif jangka panjang mengenai iklim global terutama karena $\delta^{18} \mathrm{O}$ yang merupakan indikator suhu laut dalam. Pertumbuhan lapisan es terbesar terjadi pada Kala Pleistosen saat ada lapisan es seluas benua di kedua belahan bumi (Bradley, 2015). Perubahan ini mencerminkan kombinasi beberapa faktor, yaitu: perubahan dalam posisi benua dan terbentuknya gunung dapat memengaruhi sirkulasi atmosfer, komposisi atmosfer melalui proses pelapukan, dan menyediakan daerah dataran tinggi untuk akumulasi salju. Selain itu, perubahan relatif dalam posisi orbit Bumi terhadap Matahari juga dapat memengaruhi distribusi radiasi matahari, dan perubahan kimia atmosfer, khususnya konsentrasi gas rumah kaca karbon dioksida (Zachos et al., 2008; Pagani et al., 2005; De Conto et al., 2008). Catatan sedimen laut memberi gambaran sekilas tentang bagaimana iklim bumi telah berevolusi dalam jangka waktu yang sangat lama. Memahami tentang variasi iklim dan perubahan selama Zaman Kuarter diperlukan tidak hanya untuk memahami kondisi lingkungan masa lalu, tetapi juga untuk memahami iklim saat ini. Sejak lebih dari satu dekade yang lalu, efek antropogenik di atmosfer, biosfer, dan hidrosfer telah berkembang sampai pada titik dimana mereka membentuk gaya yang sebanding dengan kekuatan-kekuatan geologi yang membentuk sejarah Bumi di masa lalu, yang mengarah pada gagasan bahwa kita sekarang memasuki era baru,
Anthroposen (Ruddiman, 1977; Crutzen, 2002; Crutzen \& Steffen, 2003).

Catatan paleoklimat yang telah ada sebelumnya, yang mencakup setidaknya periode akhir Kuarter, merupakan dasar penting untuk memahami iklim modern dan penyebab variasi dan perubahannya (Huybers \& Curry, 2006). Penelitian paleoklimat memberikan pemahaman penting tentang variabilitas sistem iklim, hubungannya dengan mekanisme yang bekerja. Hasil dari penelitian dapat memperkuat atau mengurangi dampak langsung dari perubahan tersebut. Kondisi tersebut sangat jelas dari catatan paleoklimat bahwa perubahan mendadak telah terjadi dalam sistem iklim global pada waktu-waktu tertentu di masa lalu (Alley et al., 2002).

\section{SUMBER INFORMASI PALEOKLIMAT}

Bukti kondisi iklim masa lalu biasanya tersimpan dalam jejak di alam, diantaranya: sedimen laut dan danau, endapan angin, silt, dan debu yang tidak terkonsolidasi, es, endapan gua (speleothems), bahan biologis subfosil, dan ciri geomorfologi (endapan glasial, ciri erosi). Jejak-jejak tersebut menyediakan proxy kondisi iklim masa lalu yang dapat kita manfaatkan. Catatan proxy iklim itu mengandung tanda "iklim", namun tanda tersebut mungkin relatif lemah, tergabung dalam banyak "noise" yang timbul dari efek pengaruh lain (nonklimatik) (Bradley, 2015).

Untuk mengetahui tanda iklim dari data proxy tersebut, tanda tersebut 
harus ditafsirkan terlebih dahulu. Penafsirannya melibatkan penggunaan catatan iklim modern saat ini. Database modern yang memadai dan pemahaman tentang proses alami dalam sistem iklim dan dalam proxy-proxy iklim itu sendiri merupakan prasyarat penting untuk rekonstruksi paleoklimat (Evans et al., 2013). Namun, tidak semua kondisi lingkungan di masa lalu terwakili dalam catatan periode modern saat ini. Oleh karena itu, harus disadari kemungkinan bahwa rekonstruksi paleoklimat yang salah dapat dihasilkan dari penggunaan hubungan data proxy iklim modern ketika kondisi masa lalu tidak memiliki data di dunia modern (Williams \& Jackson, 2007).

Jenis utama dari data proxy iklim yang tersedia tercantum dalam Tabel 1 . Tabel 2 menunjukkan karakteristik utama dari data proxy yang digunakan untuk rekonstruksi paleoklimat. Keakuratan dan resolusi data proxy dalam merekonstruksi paleoklimat sangat bergantung pada interval sampling, semakin kecil interval sampling maka akan semakin memiliki resolusi waktu yang pendek.

Tabel 1. Sumber utama data proxy untuk rekonstruksi paleoklimat (Bradley \& Eddy, 1991).

\begin{tabular}{|c|c|c|c|}
\hline \multirow{13}{*}{ Geologi } & \multirow{6}{*}{$\begin{array}{c}\text { Laut } \\
\text { (Core } \\
\text { sedimen } \\
\text { laut) }\end{array}$} & \multirow{4}{*}{ Sedimen biogenik } & Komposisi isotop oksigen \\
\hline & & & Kelimpahan fauna dan flora \\
\hline & & & Unsur jejak (contoh: $\mathrm{Mg} / \mathrm{Ca}$ ) \\
\hline & & & $\begin{array}{l}\text { Biomarker organik (contoh: Alkenon dan } \\
\text { Tex }_{86} \text { ) }\end{array}$ \\
\hline & & \multirow{2}{*}{ Sedimen anorganik } & Debu aeolian, puing es, ukuran butir \\
\hline & & & Rasio unsur (contoh: $\mathrm{Pa} / \mathrm{Th}$ ) \\
\hline & \multirow{7}{*}{ Darat } & \multicolumn{2}{|c|}{ Speleothems (komposisi isotop stabil dan unsur jejak) } \\
\hline & & \multicolumn{2}{|c|}{ Endapan glasial dan karakteristik erosi glasial } \\
\hline & & \multicolumn{2}{|c|}{ Endapan danau dan karakteristik erosinya } \\
\hline & & Endapan aeolian $(l o$ & umuk pasir) \\
\hline & & Karakteristik perigla & \\
\hline & & Garis pantai (ciri eu & glasioeustatik) \\
\hline & & Karakteristik pedolc & \\
\hline \multirow{4}{*}{$\begin{array}{c}\text { Glasiologi } \\
\text { (core es) }\end{array}$} & \multicolumn{3}{|c|}{ Geokimia (isotop oksigen dan hidrogen) } \\
\hline & \multicolumn{3}{|c|}{ Komposisi gas dan tekanan udara pada gelembung udara } \\
\hline & \multicolumn{3}{|c|}{ Konsentrasi mikropartikel dan komposisi unsur } \\
\hline & \multicolumn{3}{|c|}{ Sifat fisik (contoh: struktur es, temperatur lubang bor) } \\
\hline \multirow{7}{*}{ Biologi } & \multicolumn{3}{|c|}{ Lingkaran pohon (lebar, berat jenis, komposisi isotop stabil) } \\
\hline & \multicolumn{3}{|c|}{ Serbuk sari (jenis, kelimpahan relatif, dan/atau konsentrasi absolut) } \\
\hline & \multicolumn{3}{|c|}{$\begin{array}{l}\text { Diatom, ostrakoda, dan biota lain di sedimen danau (kumpulan, kelimpahan, dan } \\
\text { geokimia, termasuk biomarker organik) }\end{array}$} \\
\hline & \multicolumn{3}{|c|}{ Serangga (karakteristik kumpulan) } \\
\hline & \multicolumn{3}{|c|}{ Koral (geokimia, fluoresensi, kecepatan pertumbuhan) } \\
\hline & \multicolumn{3}{|c|}{ Makrofosil tumbuhan (umur dan distribusi) } \\
\hline & \multicolumn{3}{|c|}{ Distribusi populasi modern } \\
\hline \multirow{2}{*}{ Sejarah } & \multicolumn{3}{|c|}{ Catatan tertulis mengenai indikator lingkungan (fenomena parameteorologi) } \\
\hline & \multicolumn{3}{|c|}{ Catatan fenologi } \\
\hline
\end{tabular}


Tabel 2. Karakteristik catatan alam (Bradley \& Eddy, 1991).

\begin{tabular}{|l|l|}
\hline \multicolumn{1}{|c|}{ Catatan } & \multicolumn{1}{c|}{ Informasi potensial } \\
\hline Catatan sejarah & $\mathrm{T}, \mathrm{P}, \mathrm{B}, \mathrm{V}, \mathrm{L}, \mathrm{S}$ \\
\hline Lingkaran pohon & $\mathrm{T}, \mathrm{P}, \mathrm{B}, \mathrm{V}, \mathrm{S}$ \\
\hline Sedimen danau & $\mathrm{T}, \mathrm{B}, \mathrm{M}, \mathrm{P}, \mathrm{V}, \mathrm{C}_{\mathrm{W}}$ \\
\hline Koral & $\mathrm{C}_{\mathrm{w}}, \mathrm{L}, \mathrm{T}, \mathrm{P}$ \\
\hline Core es & $\mathrm{T}, \mathrm{P}, \mathrm{C}_{\mathrm{w}}, \mathrm{B}, \mathrm{V}, \mathrm{M}, \mathrm{S}$ \\
\hline Serbuk sari & $\mathrm{T}, \mathrm{P}, \mathrm{B}$ \\
\hline Speleothems & $\mathrm{C}, \mathrm{W}, \mathrm{T}, \mathrm{P}, \mathrm{V}, \mathrm{B}$ \\
\hline Paleosol & $\mathrm{T}, \mathrm{P}, \mathrm{B}$ \\
\hline Loess & $\mathrm{P}, \mathrm{B}, \mathrm{M}$ \\
\hline Ciri geomorfologi & $\mathrm{T}, \mathrm{P}, \mathrm{V}, \mathrm{L}, \mathrm{P}$ \\
\hline Sedimen laut & $\mathrm{T}, \mathrm{C}$ w $, \mathrm{B}, \mathrm{M}, \mathrm{L}, \mathrm{P}, \mathrm{S}$ \\
\hline
\end{tabular}

Keterangan : $\mathrm{T}$, temperatur; $\mathrm{P}$, presipitasi, kelembaban; $\mathrm{C}$, komposisi kimia udara $\left(\mathrm{C}_{\mathrm{a}}\right)$ atau air $\left(\mathrm{C}_{\mathrm{w}}\right)$; $\mathrm{B}$, informasi biomassa atau pola vegetasi; $\mathrm{V}$, erupsi vulkanik; $\mathrm{M}$, variasi daerah geomagnetik; L, permukaan laut; $\mathrm{S}$, aktivitas matahari.

Tidak semua catatan paleoklimat adalah indikator yang sensitif terhadap perubahan iklim yang tiba-tiba. Catatan yang berbeda memiliki tingkat kekurangannya masing-masing (Bradley, 2015). Misalnya, serbuk sari telah digunakan sebagai indikator perubahan iklim masa lalu. Namun tidak semua spesies tanaman merespon perubahan iklim secara mendadak pada tingkat yang sama, sehingga terkadang sulit untuk menilai kecepatan perubahan iklim dari indikator serbuk sari. Beberapa spesies mungkin memerlukan waktu hingga beberapa ratus tahun untuk menyesuaikan diri dengan perubahan iklim yang tibatiba, sementara perubahan vegetasi di wilayah lain merespon dengan cepat perubahan iklim yang tiba-tiba (Birks \&
Birks, 2008).

Fosil serangga (di sedimen danau dan endapan gambut) dapat memberikan bukti pendukung yang berharga karena populasi serangga seringkali sangat mobile dan sensitif terhadap fluktuasi suhu. Studi tentang catatan paleoklimat yang menerus dapat membantu mengetahui secara akurat kejadian iklim, di masa lalu, dan untuk alasan ini, catatan sedimen yang terus-menerus biasanya digunakan sebagai kerangka acuan paleoklimat untuk fluktuasi iklim jangka panjang yang tercatat di darat (Kukla, 1977). 


\section{SEDIMEN LAUT}

Lautan merupakan sumber informasi paleoklimat yang sangat penting yang menempati lebih dari $70 \%$ permukaan bumi. Sekitar 6 hingga 11 miliar metrik ton sedimen terakumulasi di cekungan laut setiap tahunnya, dan ini memberikan catatan mengenai kondisi iklim di dekat permukaan laut atau benua disekitarnya (Bradley, 2015). Komponen biogenik mencakup sisa-sisa organisme plankton dan bentos, yang memberikan catatan sirkulasi iklim dan samudra pada masa lalu. Dalam hal suhu dan salinitas air permukaan, oksigen terlarut di perairan laut dalam, nutrisi atau konsentrasi unsur (Gooday, 2003; Jorissen et al., 2007; Kucera, 2007; Rosenthal, 2007). Sebaliknya, kelimpahan material darat terutama memberikan catatan variasi humidityaridity di benua, atau intensitas dan arah angin yang bertiup dari daratan ke lautan, dan model transportasi sedimen lainnya ke, dan di dalam lautan (erosi fluvial, ice rafting, arus, turbidit. Sedimen laut juga mengandung biomarker (molekul organik yang berasal dari organisme darat atau laut), yang dapat menjadi proxy yang berguna untuk kondisi paleoseanografi atau kondisi paleoenvironmental (Gaines et al., 2009).

Endapan sedimen laut yang digunakan untuk proxy kuantitatif biasanya berupa mikrofosil (karena jumlahnya yang melimpah, dan umumnya terawetkan dengan baik), seperti foraminifera (calcareous zooplankton, dan zoobenthos), coccolithopores (calcareous algae), diatom (siliceous algae), dan juga radiolaria dan sillicoflagellates (siliceous zooplankton). Sebagai contoh, perubahan kelimpahan temporal foraminifera, dan diatom; rasio $\mathrm{Mg} / \mathrm{Ca}$ yang dihitung dari cangkang foraminifera; indeks alkenone jenuh yang dihitung dari fosil coccolithopore juga dapat dijadikan proxy untuk menghitung paleotemperatur permukaan laut (Tabel 3). 
Tabel 3. Hubungan proxy dan variabilitas (Herho, 2017).

\begin{tabular}{|c|c|}
\hline Proxy & Variabilitas parameter iklim \\
\hline $\begin{array}{l}\text { Dinamika populasi diatom (teknik transfer } \\
\text { fungsi ) }\end{array}$ & $\begin{array}{l}\text { Temperatur permukaan laut, ekstensi es di laut, perubahan } \\
\text { pada sirkulasi permukaan laut }\end{array}$ \\
\hline Dinamika populasi radiolaria & $\begin{array}{l}\text { Karakteristik massa air laut bawah permukaan, perubahan } \\
\text { sirkulasi }\end{array}$ \\
\hline$\delta^{18} \mathrm{O}$ dari spesies diatom tertentu & $\begin{array}{l}\text { Temperatur permukaan laut, salinitas, volume es, pelepasan } \\
\text { air tawar }\end{array}$ \\
\hline $\begin{array}{l}\delta^{18} \mathrm{O} \text { dari spesies foraminifera bentonik - } \\
\text { planktonik tertentu }\end{array}$ & $\begin{array}{l}\text { Temperatur permukaan laut dan salinitas yang berkaitan } \\
\text { dengan kedalaman habitat spesies spesifik tersebut, } \\
\text { perlapisan laut bagian atas, volume es global, pelepasan air } \\
\text { tawar }\end{array}$ \\
\hline $\begin{array}{l}\delta^{30} \mathrm{Si} \text { dari diatom silika, dan } \delta^{15} \mathrm{~N} \text { dan } \delta^{13} \\
\mathrm{C} \text { dari materi organik diatom frustula }\end{array}$ & $\begin{array}{l}\text { Mencari perubahan dalam penggunaan nutrisi (khususnya } \\
\text { di samudera belahan bumi selatan), dan perbandingan } \\
\text { penggunaan } \mathrm{Si} / \mathrm{N}\end{array}$ \\
\hline $\begin{array}{l}\mathrm{Mg} / \mathrm{Ca} \text { dari spesies foraminifera } \\
\text { planktonik tertentu }\end{array}$ & $\begin{array}{l}\text { Temperatur laut bagian atas, berkaitan dengan kedalamanan } \\
\text { habitat spesies tertentu }\end{array}$ \\
\hline Indeks alkenone jenuh & Temperatur permukaan laut \\
\hline $\begin{array}{l}\text { Komposisi kumpulan foraminifera } \\
\text { bentonik }\end{array}$ & $\begin{array}{l}\text { Produktivitas primer, continental shelf, slope dan indikator } \\
\text { kedalaman laut, indikator arus di bagian pangkal }\end{array}$ \\
\hline $\begin{array}{l}\delta^{13} \mathrm{C} \text { dari spesies foraminifera bentonik- } \\
\text { planktonik tertentu }\end{array}$ & $\begin{array}{l}\text { Konsentrasi nutrisi di laut yang berkaitan dengan kedalaman } \\
\text { habitat masing-masing spesies, perubahan sirkulasi laut } \\
\text { dalam, fluks karbon organik ke lantai samudera }\end{array}$ \\
\hline $\begin{array}{l}\delta^{13} \mathrm{C} \text { dari material organik yang } \\
\text { melimpah, dan biomarkers }\end{array}$ & Sumber karbon organik \\
\hline $\begin{array}{l}\text { Kandungan karbonat, persentase serpih } \\
\text { dari pecahan karbonat, Indeks kelarutan } \\
\text { foraminifera }\end{array}$ & $\begin{array}{l}\text { Produktivitas, pelarutan karbonat, kedalaman lysocline, } \\
\text { alkalinitas }\end{array}$ \\
\hline Komposisi biomarker & $\begin{array}{l}\text { Mengidentifikasi sumber karbon organik ( marine } v s . \\
\text { terrigenous ), produktivitas permukaan laut, pelepasan dari } \\
\text { sungai }\end{array}$ \\
\hline $\begin{array}{l}\text { Biogenic opal dan laju akumulasi- } \\
\text { kandungan karbon organik }\end{array}$ & Produktivitas permukaan laut \\
\hline$\delta \mathrm{D}$ dari biomarker tertentu & Salinitas permukaan laut \\
\hline Perbandingan $\mathrm{C} / \mathrm{N}$, parameter Rock - Eval & Menilai sedimen marin vs material sedimen organik darat \\
\hline $\begin{array}{l}\text { Distribusi butir sedimen terrigenous } \\
\text { silisiklastik }\end{array}$ & $\begin{array}{l}\text { Pelepasan dari sungai, transportasi eolian (kecepatan dan } \\
\text { arah angin), kecepatan arus laut }\end{array}$ \\
\hline $\begin{array}{l}\text { Kerentanan magnetik (magnetic } \\
\text { susceptibility) }\end{array}$ & Masukan sedimen terrigenous \\
\hline $\begin{array}{l}\text { Konsentrasi elemen dari sedimen }(X R F- \\
\text { Scanner })\end{array}$ & $\begin{array}{l}\text { Rute transportasi awal sedimen terrigenous, proses } \\
\text { pelapukan dan erosi, ventilasi dasar air }\end{array}$ \\
\hline Kelimpahan mineral lempung & $\begin{array}{l}\text { Mengidentifikasi sumber awal dan rute yang ditempuh oleh } \\
\text { sedimen terrigenous, proses pelapukan dan erosi, sistem arus } \\
\text { laut }\end{array}$ \\
\hline $\begin{array}{l}\text { Kandungan dan petrografi dari ice rafted } \\
\text { debris }\end{array}$ & $\begin{array}{l}\text { Variasi volume es global, asal usul gunung es, aliran gunung } \\
\text { es }\end{array}$ \\
\hline
\end{tabular}




\section{INFORMASI PALEOKLIMAT DARI MATERIAL BIOLOGI PADA CORE LAUT}

Data paleoklimat dari bahan biogenik pada endapan laut berasal dari kumpulan organisme mati (thanatokenosis). Namun, thanatokenosis pada umumnya tidak langsung mewakili biokenosis (kumpulan organisme hidup). Kontaminasi yang jarang oleh spesies tertentu yang terbawa jauh oleh arus laut berskala besar, semuanya menyumbang unsur ketidakpastian dalam penentuan kondisi iklim di masa lalu (Bradley, 2015). Oleh karena masalah ini, sedimen di sebagian besar dasar laut tidak sesuai untuk rekonstruksi paleoklimat. Hal ini diilustrasikan pada Gambar 1 untuk penelitian foraminifera (Ruddiman, 1977) meskipun perlu dicatat bahwa di banyak daerah yang tidak sesuai untuk perkembangan foraminifera, sisasisa organisme lainnya, seperti diatom atau radiolaria, dapat memberikan catatan yang berguna (Crosta \& Koc, 2007).

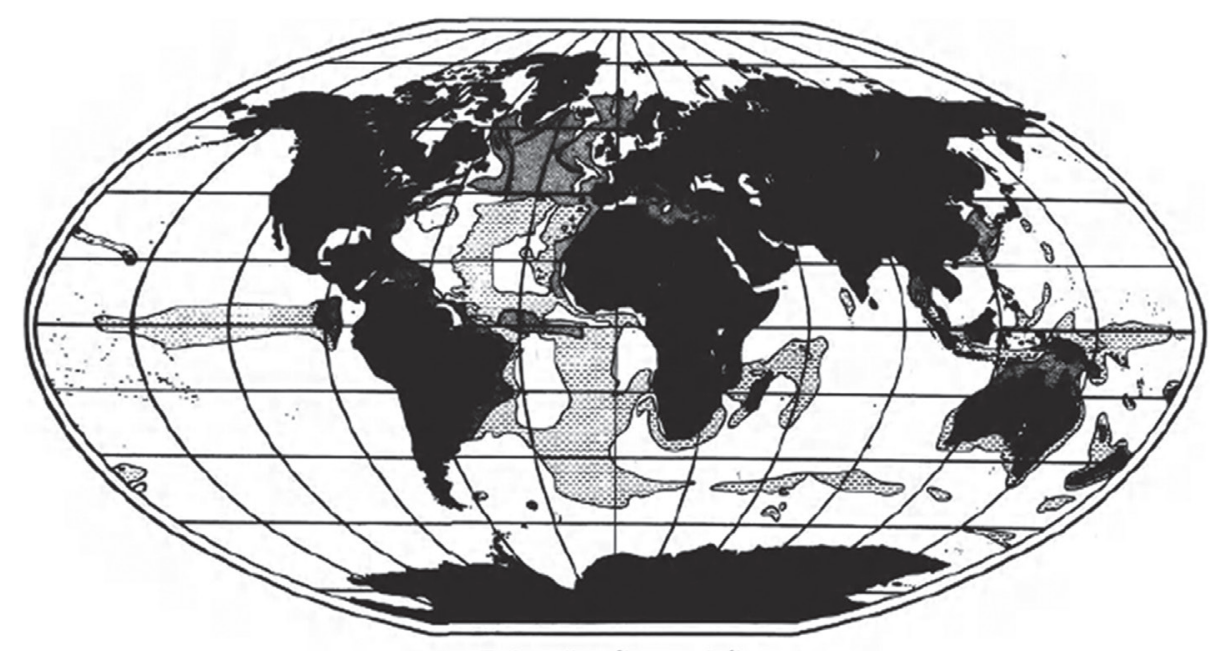

Paleoclimatic resolution

Optimal Marginal to suitable $\square$ Unsuitable

Gambar 1. Kawasan yang dianggap optimal, sedikit sesuai, dan tidak sesuai untuk studi paleoklimatologi Kuarter yang akurat dan terperinci berdasarkan kelimpahan foraminifera (Ruddiman, 1977).

Hasil paleoklimat dari sisa-sisa organisme karbonat dan silika telah dihasilkan dari empat jenis analisis yaitu: (a) komposisi isotop oksigen, terutama kalsium karbonat dalam uji foram (Ravelo \& Hillaire-Marcel, 2007); (b) interpretasi kuantitatif kumpulan spesies dan variasi spasialnya melalui waktu (Imbrie \& Kipp, 1971; Molfino et al.,
1982; Guiot \& de Vernal, 2007); (c) rasio $\mathrm{Mg} / \mathrm{Ca}$ pada tes foram, yang berkaitan dengan suhu (Rosenthal, 2007), dan (d) variasi morfologi pada spesies tertentu yang dihasilkan dari faktor lingkungan (Kucera, 2007). Sebagian besar penelitian paleoklimat berkonsentrasi pada foraminifera. Studi paleoklimat yang menggunakan coccolith, radiolaria, 
diatom, dan silikaflagellata sebagai proxy, perubahannya akan terlihat pada jumlah kelimpahan relatif dari kumpulan (Pichon et al., 1992; Guiot \& de Vernal, 2007). Variasi isotop oksigen dalam isotop pada diatom dan coccolith telah dilakukan (Shemesh et al., 1992; Crosta dan Koc, 2007). Penelitian isotop oksigen pada coccolith memberikan perkiraan paleotemperatur yang bermanfaat dan dapat memberikan data suhu permukaan laut yang lebih dapat diandalkan daripada yang didasarkan pada foram saja karena coccolith hidup secara eksklusif di zona fotik.). Namun, ada beberapa masalah dalam memperoleh cukup banyak sampel mikrofosil yang berukuran sangat kecil seperti coccolith (atau diatom).
Foraminifera bentos sangat beragam dengan ribuan spesies yang dilaporkan dari berbagai belahan dunia, namun hanya ada $\sim 40$ spesies foraminifera plankton yang ditemukan di lautan dunia modern (Saraswat, 2015). Cangkang foraminifera, khususnya foraminifera bentos, dilakukan untuk menunjukkan variasi ukuran, ornamen dan bentuk yang luas, dari kamar tunggal (unilocular) hingga kamar yang disusun dalam satu, dua atau banyak barisan linier (uniserial, biserial dan multiserial) serta kamar yang berbentuk melingkar (bentuk spiral). Cangkang foraminifera plankton pada umumnya memiliki ruang bulat dan sangat berlubang dan juga bukaan yang relatif besar. Beberapa contoh foraminifera plankton dan bentos disajikan pada Gambar 2 dan 3.
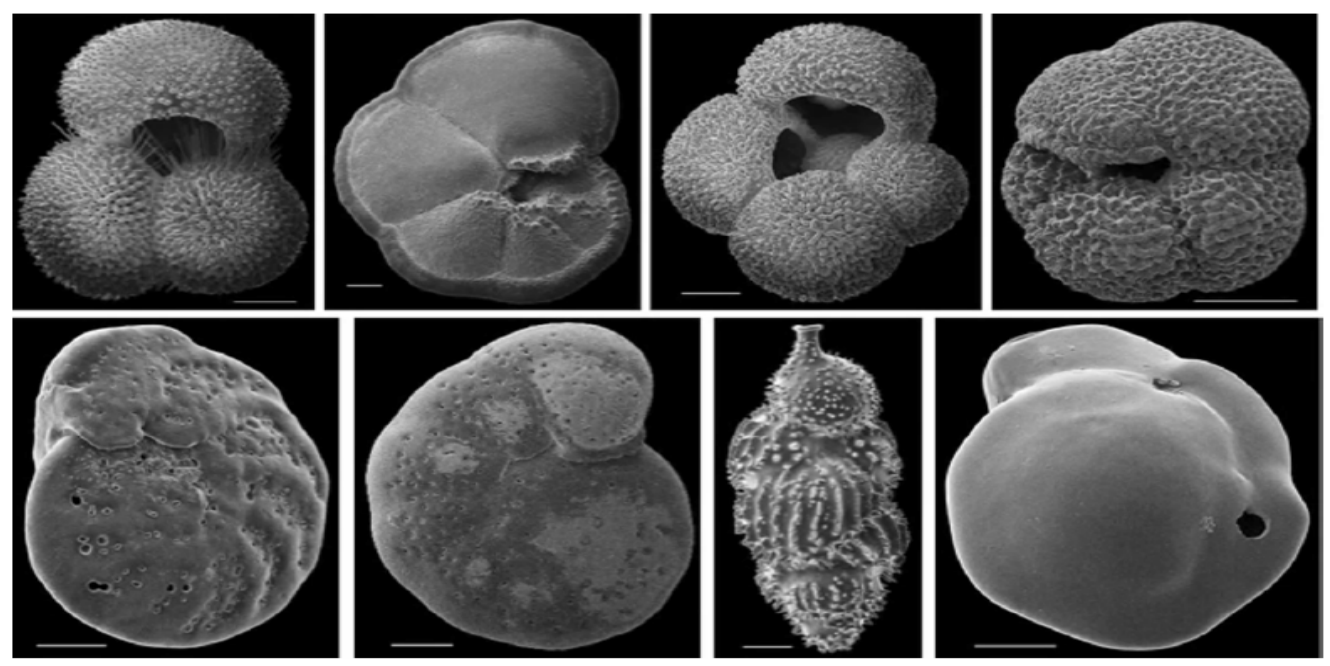

Gambar 2. Contoh foraminifera plankton dan bentos dalam penelitian paleooseanografi Atas/foraminifera plankton Globigerinoides ruber, Globorotalia menardii, Globigerina bulloides, Neogloboquadrina incompta (juga dikenal sebagai Neogloboquadrina pachyderma, dextral atau right coiling). Bawah/ Foraminifera bentos Planulina wuellerstorfi, Cibicidoides cicatricosus, Uvigerina peregrine, Oridorsalis umbonatus. (Bradley, 2015). 

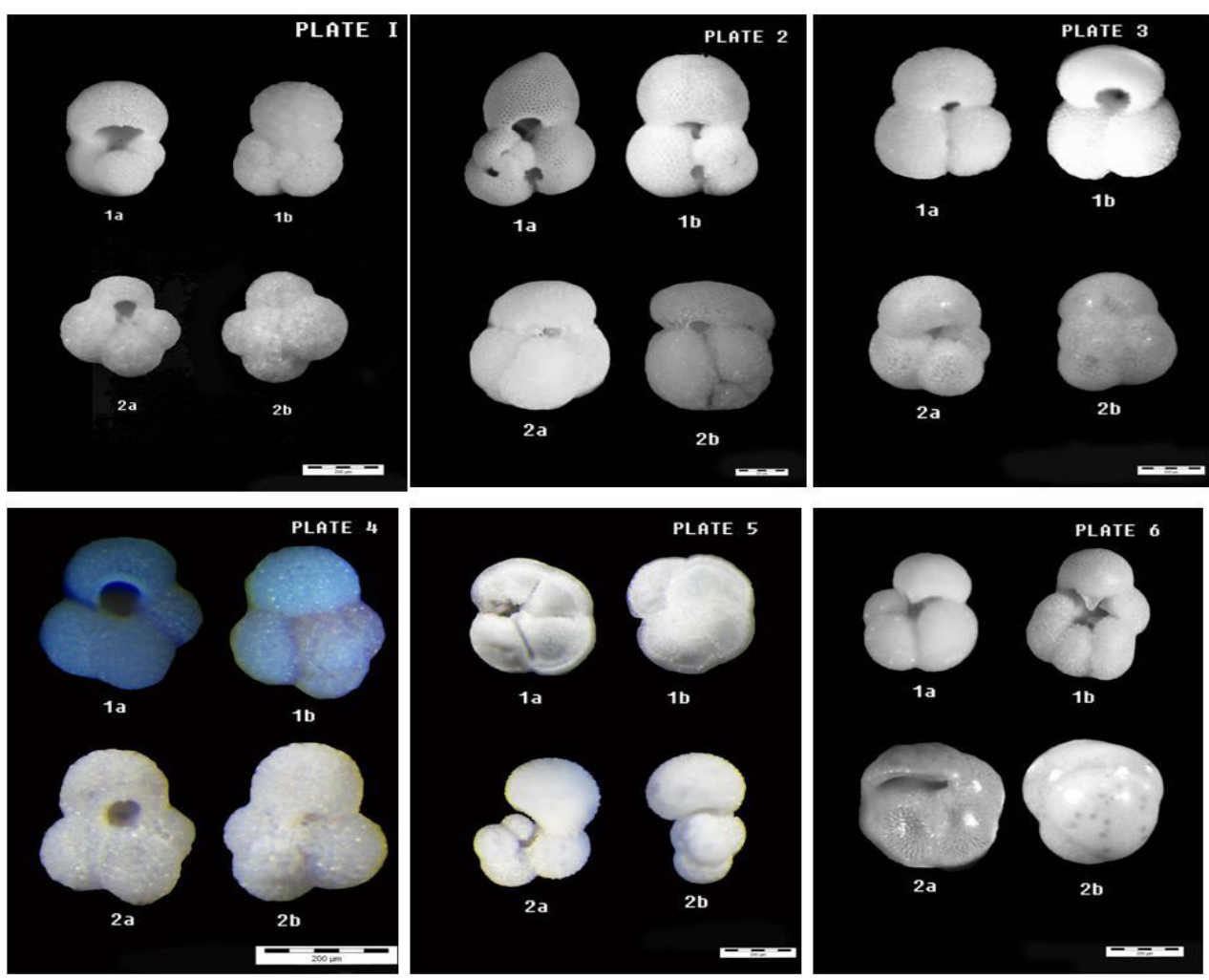

Gambar 3. Cangkang foraminifera plankton (Sijinkumar \& Nath, 2012).

Menurut Saraswat (2015) variasi kelimpahan dan morfologi cangkang foraminifera adalah respon adaptif foraminifera terhadap perubahan lingkungan yang didiami foraminifera. Dengan demikian, perubahan bentuk cangkang foraminifera sebagai respon terhadap perubahan iklim, dapat diterapkan untuk menyimpulkan kondisi lingkungan masa lalu.

Karakter dasar dari foraminifera adalah adanya cangkang/test yang membentuk kamar-kamar yang dihubungkan oleh pori-pori halus (foramen). Cangkang foraminifera dapat terbentuk dari zat-zat yang gampingan, silikaan, kitin ataupun aglutin yang sangat resisten, sehingga golongan ini banyak yang terawetkan sebagai fosil. Berbagai karakteristik dari cangkang foraminifera yang telah digunakan untuk menyimpulkan variasi iklim masa lalu meliputi:

1. Jumlah foraminifera total

2. Ratio bentik : plankton

3. Indeks fragmentasi foraminifera

4. Fraksi ukuran foraminifera

5. Kumpulan spesies

6. Kelimpahan spesies

7. Ukuran/diameter test

8. Arah putaran

9. Rata-rata jumlah kamar

10. Ukuran proloculus 


\section{KUMPULAN SPESIES FORAMINIFERA}

Spesies foraminifera tertentu lebih menyukai kondisi lingkungan yang terbatas atau dengan kondisi tertentu, sementara lainnya tinggal dalam berbagai kondisi air laut. Kelompok spesies yang menghuni lingkungan yang terbatas disebut sebagai kumpulan spesies (Saraswat, 2015). Kumpulan spesies sering diidentifikasi dengan analisis klaster dan karakteristik kumpulan spesies mewakili parameter lingkungan tertentu seperti bahan organik, oksigen terlarut, ukuran butiran, kedalaman air, dapat bervariasi dari satu wilayah ke wilayah lainnya sehingga kumpulan spesies tersebut mewakili kondisi lingkungan tertentu di suatu wilayah (Murray, 1973; Lutze \& Coulbourn, 1984). Oleh karena itu, variasi temporal pada kumpulan spesies tersebut diterapkan untuk menyimpulkan variasi kondisi lingkungan dan merupakan salah satu proxy foraminifera yang paling banyak digunakan untuk menyimpulkan variasi iklim bumi (Gupta, et al., 2001). Penerapan kumpulan spesies lebih disukai daripada kelimpahan relatif spesies individu karena jumlah individu yang biasanya signifikan secara statistik mewakili kelompok spesies daripada spesies individu (Saraswat, 2015).

\section{KELIMPAHAN SPESIES FORAMINIFERA}

Kelimpahan relatif dari setiap spesies dapat dihitung dengan memilih minimal 300 spesimen foraminifera dari sampel yang representatif dan kemudian dengan membagi jumlah spesimen spesies dengan jumlah total tes foraminifera yang diambil dari keseluruhan perwakilan (Saraswat, 2015). Kelimpahan relatif spesies foraminifera bentos dihitung dalam fraksi $>63 \mu \mathrm{m}$, sedangkan spesies foraminifera plankton berada pada fraksi $>125 \mu \mathrm{m}$ atau $>150 \mu \mathrm{m}$. Fraksi yang relatif kasar diambil untuk menghitung kelimpahan relatif foraminifera plankton karena identifikasi spesies dimungkinkan hanya pada fraksi kasar ini. Foraminifera plankton memiliki ukuran rata-rata biasanya $>125 \mu \mathrm{m}$. Studi foraminifera dari sedimen permukaan dan cekungan sedimen menunjukkan perubahan yang signifikan dalam kelimpahan spesies foraminifera dengan perubahan kondisi lingkungan sekitar (Rao et al., 2013). Oleh karena itu, kelimpahan perubahan spesies foraminifera plankton maupun bentos telah diterapkan untuk menyimpulkan perubahan paleoklimatik. Beberapa penelitian telah menggunakan kelimpahan spesies untuk merekonstruksi perubahan kondisi lingkungan. Sebagai contoh, foraminifera bentos Asterorotalia trispinosa, berlimpah di daerah berbutir halus salinitas rendah dari Teluk Benggala (Rao et al., 2013). Selain itu, kelimpahan relatif juga telah digunakan untuk merekonstruksi perubahan monsoon Holosen akhir (Panchang \& Nigam, 2012). Selanjutnya, variasi dalam kelimpahan spesies foraminifera bentos Epistominella exigua telah diterapkan untuk menyimpulkan perubahan terakhir dalam produktivitas bahan organik (Saraswat et 
al., 2005). Variasi temporal dalam kelimpahan Globigerina bulloides telah sangat sering digunakan untuk menyimpulkan produktivitas masa lalu dari Samudera Hindia. Kelimpahan dan diameter spesies foraminifera plankton Orbulina universa dipengaruhi oleh suhu air laut dan salinitas dan dengan demikian, telah digunakan untuk menyimpulkan suhu dan salinitas masa lalu dari Samudera Hindia (Nigam, 1990). Hilangnya berbagai Globigerinoides ruber pink dari India dan Samudera Pasifik pada 120.000 tahun yang lalu telah digunakan sebagai datum biostratigrafi (Thompson et al., 1979).

\section{PENUTUP}

Sejarah iklim dapat memainkan peran penting tidak hanya dalam menentukan pola perubahan iklim, tetapi juga dalam mengidentifikasi proses yang terlibat serta atribusi dari faktor penyebab penjelasan proses tersebut. Inti sedimen dasar laut sangatlah berharga dalam upaya para paleoklimatolog untuk merekonstruksi perubahan iklim. Di dalam inti sedimen, banyak terkandung fosil-fosil yang dapat menceritakan sejarah iklim masa lampau. Fosilfosil yang paling berharga berasal dari hewan kecil yang bercangkang kalsium karbonat, dikenal sebagai foraminifera. Melalui penemuan fosil-fosil dari spesies foraminifera yang sama di berbagai perairan di seluruh bumi berumur sama, paleoklimatolog kemudian mampu merekonstruksikan periode dingin yang dulu pernah terjadi di bumi.

\section{DAFTAR PUSTAKA}

Alley, R.B., J. Marotzke, W.D. Nordhaus, J.T. Overpeck, D.M. Peteet, R.A. Pielke Jr., R.T. Pierrehumbert, R.B. Rhines, T.F. Stocker, L.D. Talley, and Wallace, J.M. 2002. Abrupt climate change. Science 299: 2005-2009.

Birks, H.J.B. and H.H. Birks. 2008. Biological responses to rapid climate change at the Younger Dryas-Holocene transition at Krakenes, western Norway. The Holocene 18: 19-30.

Bradley, R.S. and J.A. Eddy. 1991. Records of past global changes. In: Bradley, R.S. (ed.). Global Changes of the Past. University Corporation for Atmospheric Research, Colorado: 5-9.

Bradley, R. S. 2015. Paleoclimatology: reconstructing climates of the Quaternary (Third edition). Elsevier, Inggris. 696 pp.

Crosta, X. and N. Koc. 2007. Diatoms: from micropaleontology to isotope geochemistry. In: Hillaire-Marcel, C., A. de Vernal (eds.). Proxies in Late Cenozoic Paleoceanography. Elsevier, Amsterdam:327-370.

Crutzen, P.J. 2002. Geology of Mankind. Nature 415: 23. doi : 10. 1038 / 415023a

Crutzen, P.J. and W. Steffen. 2003. How long have we been in the 
Anthropocene Era? Climate

Change Journal 61: 251-257.

DeConto, R.M., D. Pollard, P.A. Wilson, H. Palike, C.H. Leare, and M. Pagani. 2008. Thresholds for Cenozoic bipolar glaciation. Nature Journal. 455: 652-657.

de Vernal, A., F. Eynaud, M. Henry, C. Hillaire-Marcel, L. Londeix, S. Mangin, J. Matthiessen, F. Marret, T. Radi, A. Rochon, S. Solignac, and J. Turon. 2005. Reconstruction of seasurface conditions at middle to high-latitudes of the Northern Hemisphere during the Last Glacial Maximum (LGM) based on dinoflagellate cyst assemblages. Quaternary Science Reviews 24: 897-924.

de Vernal, A. and F. Marret. 2007. Organic-walled dinoflaggellate cysts: tracers of sea-surface conditions. In: Hillaire-Marcel, C., de Vernal, A. (eds.). Proxies in Late Cenozoic Paleoceanography. Elsevier, Amsterdam: 371-408.

Duplessy, J.C., P.L. Blanc, and A.W.H. Be. 1981. Oxygen-18 enrichment of planktonic foraminifera due to gametogenic calcification below the euphotic zone. Science Journal 213: 1247 1250.

Evans, M.N., S.E. Tolwinski-Ward, D.M. Thompson, and K.J. Anchukaitis. 2013.
Applications of proxy system modeling in high resolution paleoclimatology. Quaternary Science Reviews 76: 16-28.

Gaines, S.M., G. Eglinton, and J. Rullkotter. 2009. Echoes of Life: What Fossil Molecules Reveal About Earth History. Oxford University Press, England. 355 pp.

Gooday, A. 2003. Benthic foraminifera (Protists) as tools in paleoceanography: environmental influences on faunal characteristics. Advance Marine Biology 46: 1-90.

Guiot,J., andA.deVernal,A.2007.Chapter thirteen transfer functions: methods for quantitative paleoceanography based on microfossils. Developments in marine geology 1: 523-563.

Gupta, A. K., S. Joseph, and E. Thomas, E. 2001. Species diversity of Miocene deepsea benthic foraminifera and watermass stratification in the northeastern Indian Ocean. Micropaleontology 47: 111124.

Haq, B.U. and A. Boersma. 1978. Introduction to marine micropaleontology. Elsevier, North Holland, New York. 376 pp.

Hay, W.W. 1974. Studies in Paleoceanography. Special 
Publication No. 20. Society of Economic Paleontologists and Mineralogists, Tulsa: 1-5.

Herho, S.H.S. 2017. Paleoklimatologi untuk pemula. Angkasa Putra, Bandung. 113 hal.

Huybers, P. and W. Curry. 2006. Links between annual, Milankovitch and continuum temperature variability. Nature Journal 441: 329-332.

Imbrie, J., and N.G. Kipp. 1971. A new micropaleontological method for quantitative paleoclimatology: Application to a Late Pleistocene Caribbean core, in The Late Cenozoic Glacial Ages, K. Turekian (ed). Yale Univ. Press, New Haven, Conn.: 71-181.

Jorissen, F.J., C. Fontanier, and E. Thomas, E. 2007. Paleoceanographic proxies based on deepsea benthic foraminiferal assemblage characteristics. In: Hillaire-Marcel, C., A. de Vernal, A. (eds.), Proxies in Late Cenozoic Paleoceanography. Elsevier, Amsterdam: 263-325.

Kukla, G.J. 1977. Pleistocene land-sea correlations. I. Europe. Earth Science Reviews 13: 307-374.

Kucera, M. 2007. Planktonic foraminifera as tracers of past oceanic conditions. In: HillaireMarcel, C., A. de Vernal (eds.), Proxies in Late Cenozoic
Paleoceanography. Elsevier, Amsterdam: 213-262.

Lutze, G. and W. Coulbourn. 1984. Recent benthic Foraminifera from the continental margin of northwest Africa: community structure and distribution. Marine Micropaleontology 8: 361-401.

Molfino, B., N. Kipp, and J. Morley.1982. Comparison of Foraminiferal, Coccolithophorid, and Radiolarian Paleotemperature Equations: Assemblage Coherency and Estimate Concordancy. Quaternary Research 17(3): 279313.doi:10.1016/00335894(82)90025-4

Murray, J.W., 1973. Distribution and ecology of benthic foraminiferids. Heinemann Educational Books, London. $274 \mathrm{p}$.

Nigam, R. 1990. Palaeoclimatic implications of size variation in Orbulina universa in a core from the North Indian Ocean. Current Science 59: 46-47.

Pagani, M., J.C. Zachos, K.H. Freeman, B. Tipple, and S. Bohaty, 2005. Marked decline in atmospheric carbon dioxide concentrations during the Paleogene. Science 309(5734): 600-603.

Panchang, R. and R. Nigam. 2012. High resolution climatic records 
of the past $\sim 489$ years from Central Asia as derived from benthic foraminiferal species, Asterorotalia trispinosa. Marine Geology 307: 88-104.

Pichon, J. J., L.D. Labeyrie, G. Bareille, M. Labracherie, J. Duprat, and J. Jouzel. 1992. Surface water temperature changes in the high latitudes of the Southern Hemisphere over the last glacial interglacial cycle. Paleoceanography and Paleoclimatology 7(3): 289318.

Rao, N.R., M. Jayaprakash, and P.M. Velmurugan. 2013. The ecology of Asterorotalia trispinosa New insights from Muthupet Lagoon, southeast coast of India. Journal Foraminiferal Res. 43: 14-20.

Ravelo, A. C., and C, Hillaire-Marcel. 2007. Chapter eighteen the use of oxygen and carbon isotopes of foraminifera in Paleoceanography. Development in Marine Geology 1: 735-764. doi : $10.1016 / \mathrm{s} \quad 1572-5480$ 01023-8

Rosenthal, Y., 2007. Elemental proxies for reconstructing Cenozoic seawater paleotemperatures from calcareous fossils. In: Hillaire-Marcel, C., A. de Vernal (eds.), Proxies in Late Cenozoic Paleoceanography.
Elsevier, Amsterdam: 765-797.

Ruddiman, W.F., 1977. Investigations of Quaternary climate based on planktonic foraminifera. In: Ramsay, A.T.S. (Ed.), Oceanic Micropaleontology. Academic Press, New York, pp. 101-161.

Saraswat, R., 2015. Nondestructive foraminiferal paleoclimatic proxies: A brief insight. Proceedings Indian National Science Academy. 81(2), 381395

Saraswat, R., R. Nigam, S. Weldeab, A. Mackensen, and P.D. Naidu. 2005. A first look at past sea surface temperatures in the equatorial Indian Ocean from $\mathrm{Mg} / \mathrm{Ca}$ in foraminifera. Geophysical $R \quad e \quad s \quad e \quad a \quad r \quad c \quad h$ Letters 32(24): L24605, doi:10.1029/2005GL024093.

Shemesh, A., C. Charles, and R.G. Fairbanks. 1992. Oxygen isotopes in biogenic silica: global changes in ocean temperature and isotopic composition. Science Journal 256: 1434-1436.

Sijininkumar, A. V. and B.N. Nath, B. N. 2012. Planktic foraminifera: A potential proxy for paleoclimatic/ paleoceanography Studies. GCK Science Letters 1 (1): 2230. 
Thompson, P.,R., A.W.H. Bé, J.C. Zachos, J.C., G.R. Dickens, R.E. and Duplessy, and N.J. Shackleton. Zeebe. 2008. An early Cenozoic 1979. Disappearance of pink pigmented Globigerinoides ruber at $120,000 \mathrm{yr}$ BP in the Indian and Pacific Oceans. Nature Journal 280: 554- 557. perspective on greenhouse warming and carboncycle dynamics. Nature Journal 451: 279-283.

Williams, J.W. and S.T. Jackson, S.T. 2007. Novel climates, noanalog communities, and ecological surprises. Ecology Environtment 5: 475-482. 